\title{
Analysis of the lac $Z$ sequences from two Streptococcus thermophilus strains: comparison with the Escherichia coli and Lactobacillus bulgaricus $\beta$-galactosidase sequences
}

\author{
Craig J. Schroeder, ${ }^{1}{ }^{\dagger}$ Catherine Robert,${ }^{2}$ Gerlinde Lenzen, ${ }^{2}$ Larry L. McKay ${ }^{1}$ and \\ ANNICK MERCENIER ${ }^{2 *}$ \\ ${ }^{1}$ Department of Food Science and Nutrition, 1334 Eckles Ave, University of Minnesota, St Paul, MN 55108, USA \\ ${ }^{2}$ Transgene SA, 11 rue de Molsheim, 67000 Strasbourg, France
}

(Received 28 June 1990; revised 28 September 1990; accepted 25 October 1990)

\begin{abstract}
The lacZ gene from Streptococcus thermophilus A054, a commercial yogurt strain, was cloned on a 7.2 kb PstI fragment in Escherichia coli and compared with the previously cloned lac $Z$ gene from $S$. thermophilus ATCC 19258. Using the dideoxy chain termination method, the DNA sequences of both lac $Z$ structural genes were determined and found to be $3071 \mathrm{bp}$ in length. When the two sequences were more closely analysed, 21 nucleotide differences were detected, of which only nine resulted in amino acid changes in the proteins, the remainder occurring in wobble positions of the respective codons. Only three bases separated the termination codon for the lacS gene from the initiation codon for lac $Z$, suggesting that the lactose utilization genes are organized as an operon. The amino acid sequence of the $\beta$-galactosidase, derived from the DNA sequence, corresponds to a protein with a molecular mass of $116860 \mathrm{Da}$. Comparison of the $S$. thermophilus amino acid sequences with those from Lactobacillus bulgaricus, $E$. coli and Klebsiella pneumoniae showed 48, 35 and $32.5 \%$ identity respectively. Although little sequence homology was observed at the DNA level, many regions conserved in the amino acid sequence were identified when the $\beta$-galactosidase proteins from $S$. thermophilus, $E$. coli and $L$. bulgaricus were compared.
\end{abstract}

\section{Introduction}

The bioconversion of lactose to lactic acid is an essential process in dairy fermentations. In lactococci (previously the mesophilic, group $\mathrm{N}$ streptococci) and certain lactobacilli, lactose is phosphorylated during its uptake and converted to lactose 6-phosphate, which is then hydrolysed by a phospho- $\beta$-galactosidase $(\mathrm{Pbg})$ to yield D-glucose and galactose 6-phosphate. However, in Streptococcus salivarius subsp. thermophilus (designated

$\nmid$ Present address: Department of Food Science, 101 Holmes Hall, University of Maine, Orono, Maine 04469, USA.

Abbreviations: Ap, ampicillin; Bgal, $\beta$-galactosidase; $\mathrm{Cm}$, chloramphenicol; Em, erythromycin; ExoIII, exonuclease III; Km, kanamycin; ORF, open reading frame; PEP-PTS, phosphoenolpyruvate phosphotransferase system; $\mathrm{Pbg}$, phospho- $\beta$-galactosidase; RBS, ribosome-binding site; Tc, tetracycline; X-Gal, 5-bromo-4-chloro-3-indolyl $\beta$-D-galactopyranoside.

The nucleotide sequence data reported in this paper have been submitted to GenBank and have been assigned accession numbers M36729 (lacZ A054) and M37204 (lacZ ATCC 19258). as $S$. thermophilus throughout this paper) lactose transport is not mediated through a phosphoenolpyruvate phosphotransferase system (PEP-PTS; Poolman et al., 1989), but rather the intracellular sugar is hydrolysed by a $\beta$-galactosidase (Bgal; Somkuti \& Steinberg, 1979).

There has been growing interest in the molecular organization of genes for lactose utilization from dairy lactic acid bacteria (Alpert \& Chassy, 1988; Boizet et al., 1988; DeVos \& Simons, 1988; DeVos et al., 1989; Porter \& Chassy, 1988; Schmidt et al., 1989; Poolman et al., 1989), including those genes from species widely used in the preparation of yogurt and cheeses that require high incubation or cooking temperatures (Herman \& McKay, 1986; Poolman et al., 1989; Schmidt et al., 1989). Furthermore, homology studies of lactose genes from dairy starter organisms, which are mainly adapted to the efficient metabolism of lactose, with equivalent genes from Escherichia coli and similar organisms, for which this source of energy is minor in the natural environment, could possibly provide information about cellular efficiency and protein structure and function. 
The plasmid cloning vectors that are currently available for the dairy streptococci depend upon selection markers which encode antibiotic resistance. Since such markers are considered unsuitable for use in food fermentations, other markers, such as genes for carbohydrate utilization, should be isolated and characterized. One such example would be the Bgal gene linked to the lactose transport gene from $S$. thermophilus. Herman \& McKay (1986) reported the cloning and characterization of the lac $Z$ gene (for nomenclature, see Methods) from $S$. thermophilus. The protein encoded by this gene was analysed in $E$. coli maxicells and was determined to have a molecular mass of approximately $105000 \mathrm{Da}$ (Herman et al., 1987). The lacZ gene was localized on a $3.85 \mathrm{~kb}$ region of a $7.2 \mathrm{~kb}$ PstI-generated chromosomal fragment.

In this study, the lac $Z$ genes from two $S$. thermophilus strains, A054 (an industrial yogurt strain whose genetics has been well studied; Mercenier \& Lemoine, 1989) and ATCC 19258 (the type strain), were subjected to DNA sequence analysis. These strains differ markedly in their acid production/milk coagulation rates and in their sensitivities to various lytic $S$. thermophilus bacterio- phages. Although strain ATCC 19258 is a 'type' culture, it exhibits relatively few of the desirable characteristics of a starter culture (i.e. fast acid production, milk clotting activity, etc.). The DNA and deduced protein sequences of the lac $Z$ genes of these two strains were compared to determine whether their rate of acid production reflects functional differences in their lactose utilization genes. Sequence homologies were also examined among the Bgal genes from $S$. thermophilus, Lactobacillus bulgaricus and E. coli.

\section{Methods}

Bacterial strains and vectors. The genotypes of the bacterial strains and plasmids used in this study, with their sources, are given in Table 1. $E$. coli strains were grown at $37^{\circ} \mathrm{C}$ in YT broth medium $(8 \mathrm{~g}$ tryptone $\mathrm{1}^{-1}, 5 \mathrm{~g}$ yeast extract $\left.\mathrm{l}^{-1}, 5 \mathrm{~g} \mathrm{NaCl}^{-1}\right)$ or LB medium $\left(10 \mathrm{~g}\right.$ tryptone $\mathrm{l}^{-1}$, $10 \mathrm{~g}$ yeast extract $1^{-1}, 5 \mathrm{~g} \mathrm{NaCl}^{-1}$ ) (Miller, 1972). Agar plating media were prepared by the addition of $1.5 \%(\mathrm{w} / \mathrm{v})$ agar to broth media. Antibiotics were added in the following concentrations when needed: chloramphenicol $(\mathrm{Cm}), 25 \mu \mathrm{g} \mathrm{ml}^{-1}$; tetracycline $(\mathrm{Tc}), 15 \mu \mathrm{g} \mathrm{ml}^{-1}$; ampicillin (Ap), 50 or $100 \mu \mathrm{g} \mathrm{ml}^{-1}$.S. thermophilus strains were grown at $37^{\circ} \mathrm{C}$ or $42^{\circ} \mathrm{C}$ in $\mathrm{M} 17$ medium (Terzaghi \& Sandine, 1975) containing $5 \%(\mathrm{w} / \mathrm{v})$ glucose or in Elliker medium (Elliker et al., 1956)

Table 1. Bacterial strains and plasmid vectors

\begin{tabular}{|c|c|c|}
\hline Strain & Genotype & Reference \\
\hline \multicolumn{3}{|l|}{ E. coli } \\
\hline C600 & $\mathrm{F}^{-}$thi-1 thr-1 leuB6 lacY1 tonA21 supE44 $\lambda^{-}$ & Appleyard (1954) \\
\hline XL-1 Blue & $\begin{array}{l}\operatorname{rec} A \text { end } A 1 \text { gyrA } 96 \text { thi hsd } 17\left(\mathrm{r}_{\mathrm{k}}^{-} \mathrm{m}_{\mathrm{k}}^{+}\right) \text {supE } 44 \text { relAl } \\
\lambda^{-} \text {lac }\left[\mathrm{F}^{\prime} \text { proAB lac } I^{9} Z \mathrm{M} 15 \mathrm{Tn} 10\right]\end{array}$ & Bullock et al. (1987) \\
\hline JM107 & $\begin{array}{l}\text { endAl gyrA96 thi hsdR17 supE44 relAl } \lambda^{-} \Delta(\text { lac- } \\
\text { pro } A B),\left[\mathrm{F}^{\prime} \text { traD36 proAB } \text { lacl }^{9} \mathrm{Z} \mathrm{M} 15\right]\end{array}$ & Yanisch-Perron et al. (1985) \\
\hline \multicolumn{3}{|c|}{ PVo } \\
\hline A023 & Wild-type (yogurt starter) & This study \\
\hline A032 & Wild-type (yogurt starter) & This study \\
\hline A054 & Wild-type (yogurt starter) & This study \\
\hline A 147 & Wild-type (yogurt starter) & Poolman et al. (1989) \\
\hline ATCC 19258 & Wild-type (type culture) & Herman \& McKay (1986) \\
\hline \multicolumn{3}{|c|}{ L. lactis subsp. lactis } \\
\hline LM0230 & $\mathrm{Lac}^{-}$ & McKay et al. (1980) \\
\hline LM2301 & $\mathrm{Lac}^{-} \mathrm{Str}^{\mathrm{r}}$ & McKay et al. (1980) \\
\hline 7962 & Wild-type & Crow \& Thomas (1984) \\
\hline Plasmid & Selective marker(s) & Reference \\
\hline pBR322 & $\mathrm{Ap}^{r}, \mathrm{Tc}^{\mathrm{r}}$ & Bolivar et al. (1977) \\
\hline pUC19 & $A p^{r}$ & Yanisch-Perron et al. (1985) \\
\hline Bluescript KS & $A p^{r}$ & Stratagene Cloning Systems \\
\hline pMG4536 & $\mathrm{Km}^{r} \mathrm{Cm}^{r}$ & Gasson (1987) \\
\hline pSA3 & $\mathrm{Em}^{r} \mathrm{Cm}^{r} \mathrm{Tc}^{r}$ & Dao \& Ferretti (1985) \\
\hline pRHII6 & $\mathrm{Tc}^{r} \mathrm{LacZ}^{+}$ & Herman \& McKay (1986) \\
\hline pTG234 & $\mathrm{Cm}^{r} \mathrm{LacZ}^{+}\left(\mathrm{Km}^{\mathrm{r}}\right)^{*}$ & This study \\
\hline pTG236 & $\mathrm{Cm}^{\mathrm{r}} \mathrm{LacZ}^{+}\left(\mathrm{Km}^{r}\right)^{*}$ & This study \\
\hline pCS119 & $\mathrm{Ap}^{r} \mathrm{LacZ}^{+}$ & This study \\
\hline pCS200 & $\mathrm{Ap}^{r} \mathrm{LacZ}^{+}$ & This study \\
\hline pUM101 & $\mathrm{Em}^{\mathrm{r}} \mathrm{Cm}^{\mathrm{r}} \mathrm{LacZ}^{+}$ & This study \\
\hline
\end{tabular}

${ }^{*} \mathrm{Km}^{\mathrm{r}}$ was proven an unsuitable marker for the selection of lactococcal or streptococcal transformants. 
supplemented with $1 \%(\mathrm{w} / \mathrm{v})$ beef extract. Lactococcus lactis strains were grown in $\mathrm{M} 17 /$ glucose broth at $32^{\circ} \mathrm{C}$. When necessary, $\mathrm{Cm}$ or Em was added at a concentration of $5 \mu \mathrm{g} \mathrm{ml}^{-1}$ for streptococci and lactococci.

Nomenclature. The $\beta$-galactosidase gene, previously designated $\beta$-gal (Herman \& McKay, 1986; Herman et al., 1987), has been re-designated lac $Z$ in accordance with the rules for uniform nomenclature as proposed by Demerec et al. (1966). This gene designation is based on structural (sequence homology) and functional properties of the $S$. thermophilus gene, and brings this gene into alignment with the nomenclature used for E. coli and Salmonella typhimurium. However, because the lactose transport protein of $S$. thermophilus has a unique structure, lac $S$ is an appropriate designation for that gene (described by Poolman et al., 1989). It is our hope that researchers in related areas will incorporate the use of this nomenclature in future publications.

Reagents and chemicals. For detection of Bgal-positive subclones, 5bromo-4-chloro-3-indolyl $\beta$-D-galactopyranoside $(\mathrm{X}-\mathrm{Gal})$ was used in agar media at a concentration of $40 \mu \mathrm{g} \mathrm{ml}^{-1}$. Restriction enzymes and T4 DNA ligase were obtained from BRL and were used as directed by the supplier. Exonuclease III (ExoIII) and mung bean nuclease, used for deletion analysis, were purchased in kit form from Stratagene. For DNA sequencing of the lac $Z$ gene of ATCC 19258, dideoxy sequencing reagents and Sequenase were purchased in kit form from US Biochemical Corp., and ${ }^{32}$ P-labelled dATP was obtained from New England Nuclear. The lac $Z$ gene of strain A054 was sequenced following the procedure of Sanger et al. (1977), using the large Klenow fragment of DNA polymerase I purchased from BRL. ${ }^{32} \mathrm{P}$-radiolabelling of DNA probes was achieved as described by Maniatis et al. (1982).

DNA isolation. DNA fragments were isolated from agarose gels using a modification of the method of Winberg \& Hammerskjola (1980). DEAE membranes (BA45; Schleicher \& Schuell) replaced DEAE paper. Plasmid DNA was isolated from $E$. coli by either the rapid boiling method of Holmes \& Quigley (1981) or the method of Macrina et al. (1983).

Deletion analysis. Deletions in the lacZ gene of ATCC 19258 were generated by the procedure of Henikoff (1984) using the Stratagene ExollI deletion kit. For deletions from the Sall end of the lacZ (ATCC 19258 ) fragment, pKS200 was completely digested with $S a I$ and $K p n I$ prior to ExolII digestion. Bidirectional deletions from the PstI end were generated after first digesting pKS200 with BamHI.

Transformation. E. coli strains were transformed using the procedure of Hanahan (1983). For L. lactis, the protoplast transformation developed by Kondo \& McKay (1982) was used. Plasmid DNA was introduced into $S$. thermophilus using the spheroplast transformation procedure of Mercenier et al. (1988). Alternatively, electroporation was used to introduce DNA into $L$. lactis and $S$. thermophilus (A. Mercenier and others, unpublished).

Nucleotide sequencing procedure. A $5.6 \mathrm{~kb}$ chromosomal insert carrying the lac $Z$ gene from strain A054 was sequenced after generating multiple overlapping clones by a shotgun approach (Bankier \& Barrell, 1983) using the sequencing vectors M13tgl30 and M13tg131 (Kieny et al., 1983). Alternatively, deletions were generated from both ends of the $3.0 \mathrm{~kb}$ lacZ (ATCC 19258) fragment in pCS200 using the method described above. After restriction digestion, and ExoIII and mung bean nuclease treatments, the deletion fragments were released from the original plasmid vector DNA and subsequently subcloned into the M13 cloning/sequencing vectors M13mp18 and M13mp19 (Yanisch-Perron et al., 1985). In addition, EcoRI and Bg/II restriction fragments were subcloned directly into M13 vectors to cover regions not accessible for sequencing using the deletion products. Dideoxy sequencing of the lacZ (ATCC 19258) gene was achieved using a modified T7 DNA polymerase (Sequenase; Sanger et al., 1977;
Tabor \& Richardson, 1987). Synthetic primers were employed to complete the sequence of both strands of DNA. The IntelliGenetics DNA and protein analysis package on a SUN 2/120 computer, programs purchased from DNA-Star (Madison, WI, USA), and the Larson \& Messing (1982) DNA sequence analysis programs facilitated sequence analysis of both $l a c Z$ genes.

$\beta$-Galactosidase assays. Cell-free extracts of $S$. thermophilus ATCC 19258 were prepared in the following manner. Cultures were grown overnight at $42{ }^{\circ} \mathrm{C}$ in $200 \mathrm{ml} \mathrm{M} 17$ broth supplemented with $1 \%$ (w/v) maltose or lactose as carbon source. After harvesting, the cells were washed twice with $0.1 \mathrm{M}$-sodium phosphate buffer $(\mathrm{pH} 7.0)$ and resuspended in $5 \mathrm{ml}$ fresh buffer. Mechanical breakage of the cells was achieved using an Eaton pressure cell, and cell debris was removed by centrifugation. Bgal activity was then determined by the method of Miller (1972). For S. thermophilus A054, enzyme activity was determined following the procedure described by Somkuti \& Steinberg (1979) after lysis of a spheroplast suspension prepared as described by Mercenier et al. (1988).

\section{Results}

Subcloning of the $5 \cdot 7 \mathrm{~kb}$ fragments carrying the lac $Z$ gene from strains A054 and ATCC 19258

The lac $Z$ gene from the yogurt starter strain A054 was cloned on a $7.2 \mathrm{~kb}$ Pst $\mathrm{I}$ fragment into $\mathrm{pBR} 322$, as reported previously for the $l a c Z$ gene from $S$. thermophilus ATCC 19258 (Herman \& McKay, 1986). This plasmid was designated pTG234 and is equivalent to pRH116 described by Herman \& McKay (see Fig. 1). Comparative restriction and deletion analyses of pRH116 and pTG234 showed physical similarity between the respective chromosomal inserts. The $5.7 \mathrm{~kb}$ PstI-SalI lacZ (A054) fragment was subcloned from pTG234 into pMG4536 (Gasson, 1987) downstream from the promoter $\mathrm{A}\left(\mathrm{P}_{\mathrm{A}}\right)$ of this plasmid. The resulting construct, pTG236, was introduced into $E$. coli JM107 (a Lac $^{-}$recipient), L. lactis LM2301 and S. thermophilus A054. Bgal activity was detected in the two former strains by streaking the recombinant strains on $\mathrm{X}-\mathrm{Gal}$ medium. In A054, the intracellular enzyme activity was measured and found to be increased only by a factor of two over that observed without pTG236 (data not shown).

The $5.7 \mathrm{~kb}$ PstI-SalI lacZ (ATCC 19258) fragment from $\mathrm{pRH} 116$ was subcloned into the corresponding sites of pUC19 (Yanisch-Perron et al., 1985), and the new Bgal-positive construct was designated pCS119 (Fig. 1). Using the BamHI-SphI sites provided by the pUC19 portion of pCS119, the lac $Z$ fragment was further subcloned into the BamHI-SphI sites of pSA3 (Dao \& Ferretti, 1985) and transformed into E. coli. Plasmid DNA of the new construction, pUM101 (Fig. 1), was used to transform L. lactis LM0230. Transformants were Bgal positive on X-Gal plates, but only after $36-48 \mathrm{~h}$, suggesting that enzyme activity or production in LM0230(pUM101) was lower than for LM2301 


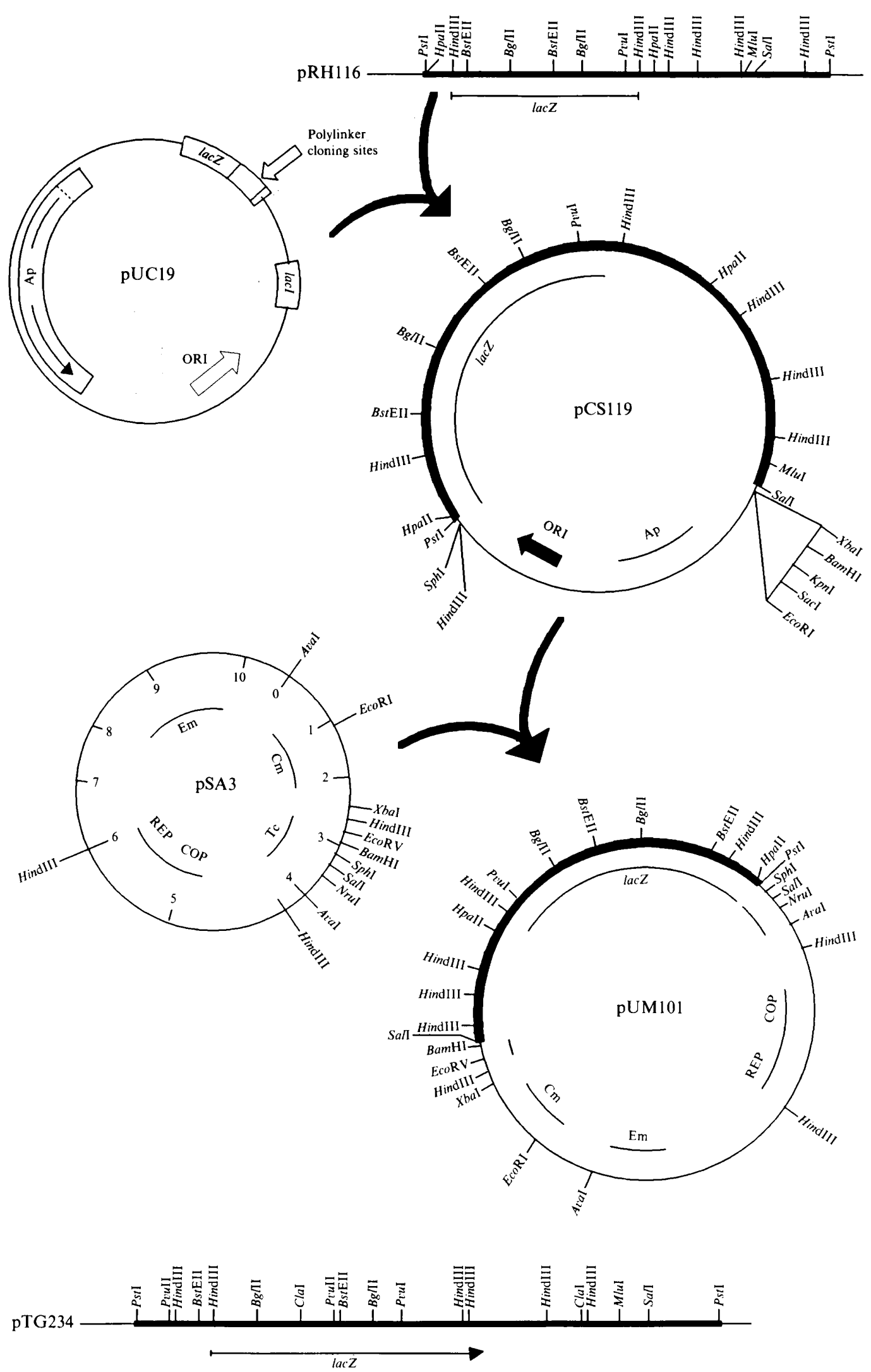

Fig. 1. Subcloning of the PstI-Sall lacZ fragment from S. thermophilus ATCC 19258 and construction of pCS119 and pUM101, the latter being an E. coli-streptococcal shuttle vector containing lacZ (ATCC 19258). A linear map of the PstI-PstI fragment from $S$. thermophilus A054 is also included. 
(pTG236). Additional Bgal assays showed approximately 100 -fold lower enzyme activity in $L$. lactis when compared with the same gene product in $E$. coli (data not shown).

\section{Analysis of the $5.6 \mathrm{~kb}$ insert of A054}

For sequencing purposes, overlapping fragments of the lacZ (A054) insert were generated using a shotgun approach (Bankier \& Barrell, 1983). This required prior in vitro mutagenesis of the unique $M l u \mathrm{I}$ site present in pTG234 and resulted in the generation of a $5.6 \mathrm{~kb}$ Pst IPstI fragment. This fragment was isolated, religated to itself, and further sonicated to produce a population of random blunt-end fragments. These fragments were then subcloned into the SmaI sites of M13tg130 and M13tg131. As a result, 32 overlapping clones were generated for the sequencing of one strand, while 38 were isolated for sequencing of the other strand (data not shown).

To determine whether the lac $Z$ gene resides on the same DNA fragment in different strains of $S$. thermophilus, chromosomal DNA from four industrial yogurt starter cultures (A023, A032, A054 and A147) was isolated and digested with PstI. The fragments were separated by agarose gel electrophoresis and screened by Southern blot hybridization (Southern, 1975) using highstringency conditions and ${ }^{32} \mathrm{P}$-labelled lacZ (A054) gene as a probe. All $S$. thermophilus strains tested carried lac $Z$ on a $7.2 \mathrm{~kb}$ Pst $\mathrm{I}-$ PstI fragment (data not shown). When DNA from E. coli C600 (Appleyard, 1954) or L. lactis 7962 (Crow \& Thomas, 1984) was screened in the same manner, no hybridization signal was detected (data not shown) even though L. lactis 7962 produces both a Bgal and a Pbg (Crow \& Thomas, 1984).

\section{Deletion analysis of the lacZ (ATCC 19258) fragment}

In order to localize the lacZ (ATCC 19258) gene on the $5.7 \mathrm{~kb}$ Pst I-SalI fragment of pCS119, deletions were generated using ExoIII (Henikoff, 1984; see Fig. 2). DNA was first deleted from the SalI end. Restriction analysis of the deletion fragments showed that the $590 \mathrm{bp}$ HindIII fragment had previously been incorrectly mapped to the right of the large $3.0 \mathrm{~kb} H$ indIII fragment. Deletion analysis also aided in determining the location of the right end of the lacZ (ATCC 19258) gene. Isolate 137 (Fig. 2) was Bgal positive but isolate 145 was Bgal négative, indicating that one boundary of the lac $Z$ (ATCC 19258) gene was located at or near the corresponding HindIII site. The left end of the lac Z gene was localized by deleting sequences bidirectionally from the BamHI site. Isolate 68 , which retained Bgal activity, had lost approximately $600 \mathrm{bp}$ of DNA, suggesting that

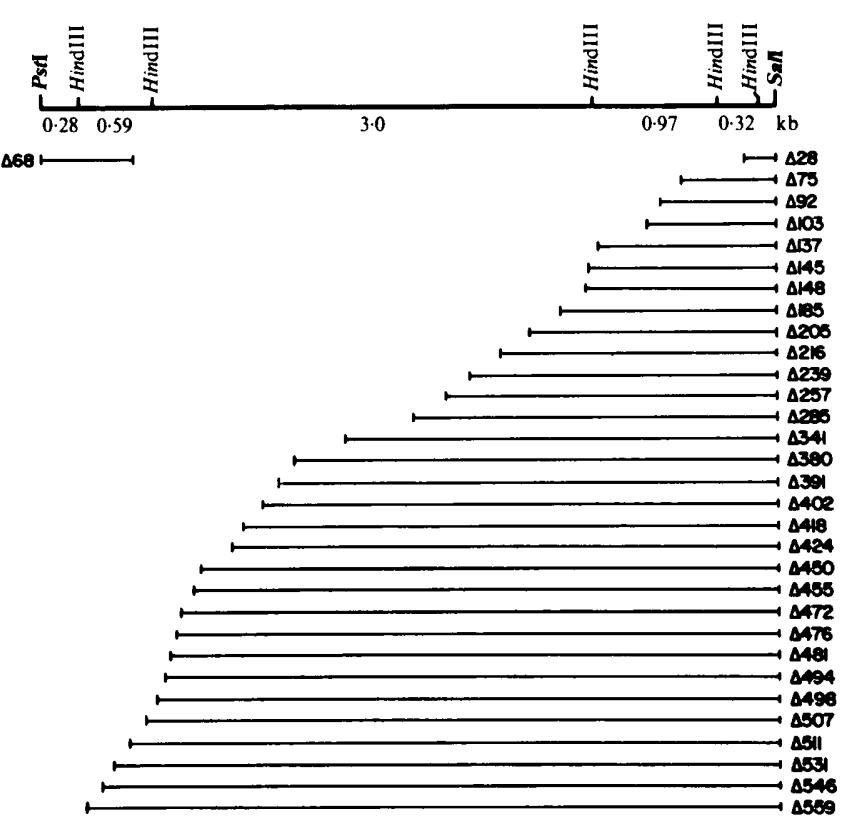

Fig. 2. Map of lacZ (ATCC 19258) fragment deletions generated using ExolII/mung bean nuclease. Deletions 28-137 and 68 were Bgal positive while deletions $145-559$ did not display enzyme activity.

the lac $Z$ structural gene resides on a $3.2 \mathrm{~kb}$ region of DNA.

Based on previous work by Herman \& McKay (1986) suggesting that the lacZ (ATCC 19258) gene might be contained on the largest HindIII fragment, the $3.0 \mathrm{~kb}$ HindIII fragment from pCS119 was subcloned into Bluescript KS (see Table 1). This fragment produced constitutive Bgal activity in the new construct, pCS200. Because enzyme activity was constitutive in Bluescript $\mathrm{KS}$, which contains an inducible $E$. coli-derived lacZ promoter upstream from the polylinker, it was thought that the $S$. thermophilus lacZ (ATCC 19258) gene carried its own promoter.

$D N A$ sequencing and comparison of the lac $Z$ genes from ATCC 19258 and A054

By nucleotide sequencing, it was determined that the lacZ genes from strains A054 and ATCC 19258 were actually contained on two HindIII fragments, one of $3098 \mathrm{bp}$, and one of $76 \mathrm{bp}$ (Fig. 1). The eight carboxyterminal residues of the protein plus the termination codon are encoded by the $76 \mathrm{bp}$ fragment. The size of the $S$. thermophilus lac $Z$ structural gene was determined to be $3071 \mathrm{bp}$ and most probably encodes a protein of 1026 amino acid residues. With a calculated average $\mathrm{pI}$ value of 5.90, the Bgal protein has a calculated molecular mass of 116860. Analysis of nucleotide percentages gave 
$-35-10$

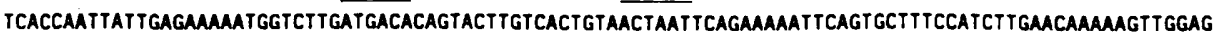

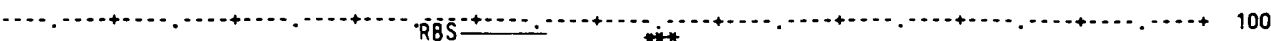

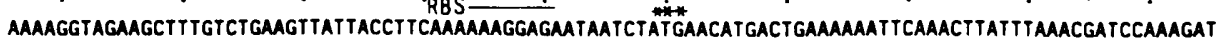

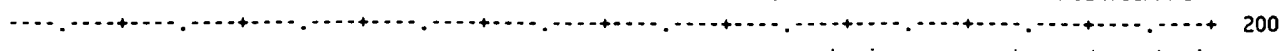

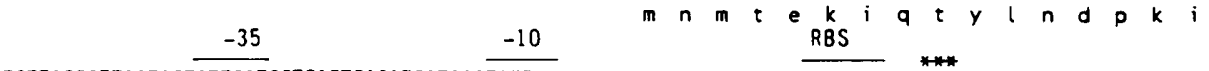

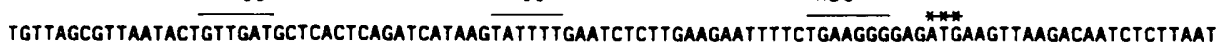

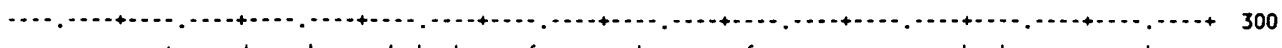
$\checkmark s \vee n t \vee d a h s d h k y f e s l e j f s e g e k k l r q s i n$

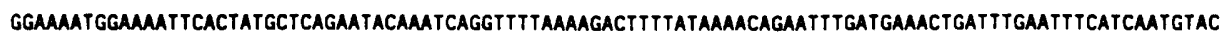

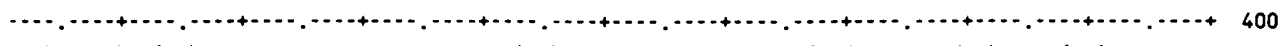
$g k * k i h y a q n t n q v l k d f y k t e f d e t d l n f i n v p$

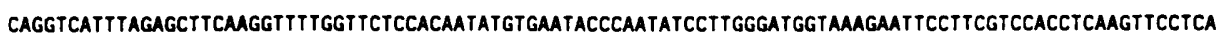

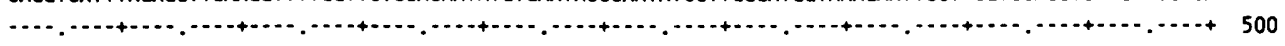

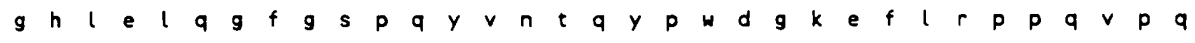

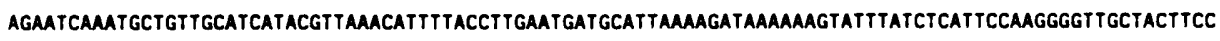

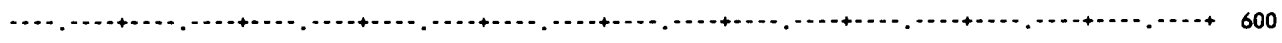
e $s, a v a s y v k h f t l n d a l k d k k v f i s f a g r a t s$

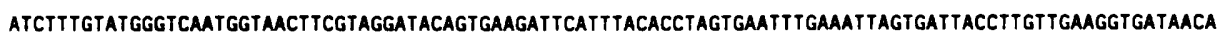
$i f \vee w \vee n g n f v g y s$ e d s f t p s e f e i s d $y l v e g d n k$

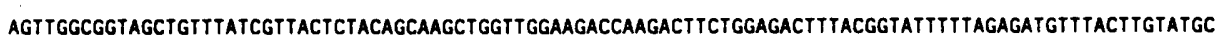

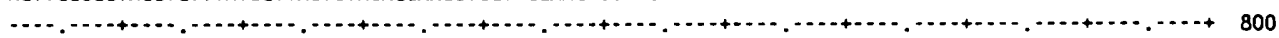

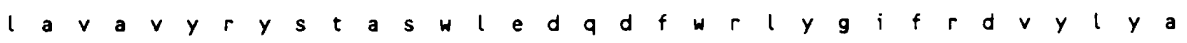

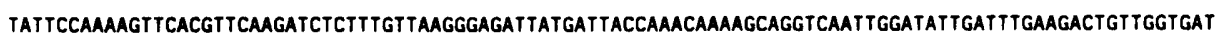

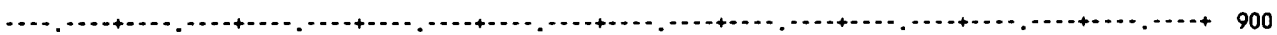

$i p k \vee h \vee q d l f v k g d y d y q t k$ a g g l d i d l k t $v g d$

tatgaagacaggaagattamutatgttctticagattatgaaggcatcgttacagaaggtgatgcatctgttaatgGtgacggtgaactatctgtaagtc $y e d k k i k$ y $v i s d y e g i v t e g d a s v n g d g e l s v s$ l

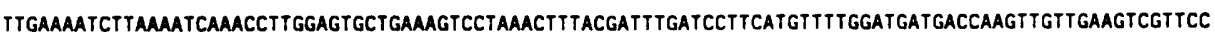

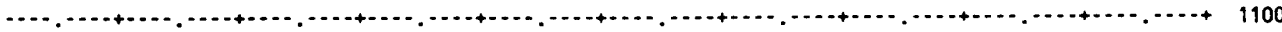

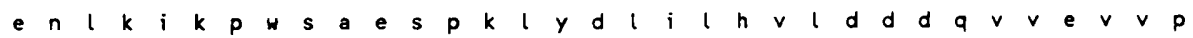

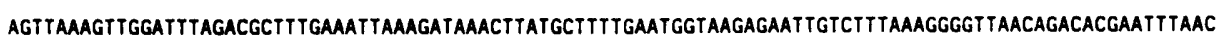

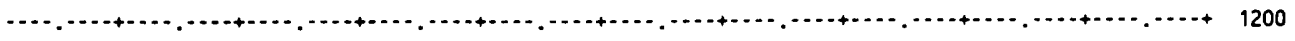
$\vee k \vee g f r r f e j k d k l m l l n g k r i v f k g \vee n r h e f n$

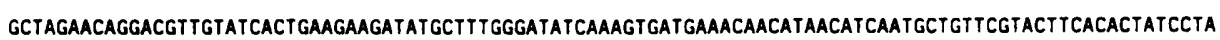

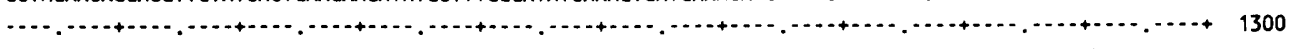

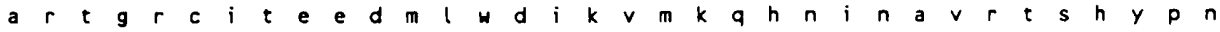

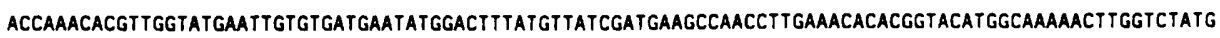

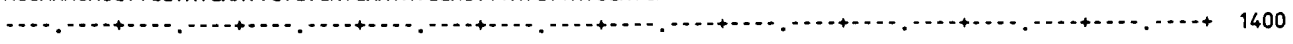
q t $r$ w y e l c d e y g l y $v$ i d e a n l e t h g t wa k l g l c

CGAACCTTCATGGAATATCCCAGCTAGTGAACCAGAATGGTTGCCTGCTIGTITGGATCGTGCCAATAACATGT TCCAACGCGATAAGAACCACGCTAGT

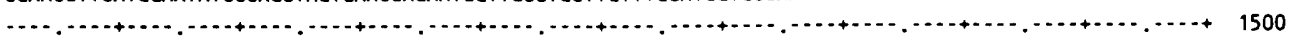
e p s w i p a s e p e w l p a c l d $r$ a $n n m f q r d k n h$ a $s$

GITATCATTTGGTCTTGTGGTAATGATCATATGCTGGTAAAGATATTGCTGACATGGCTGATTACTTCCGTAGTGTTGACAATACTCGTCCAGTTCACT

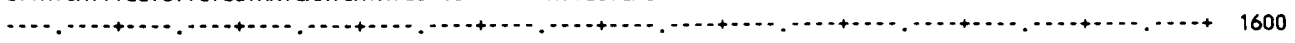

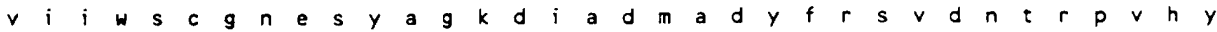

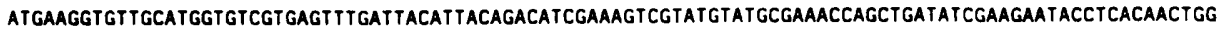

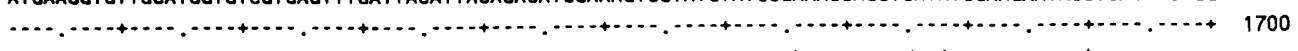

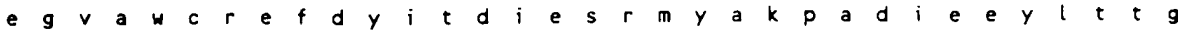




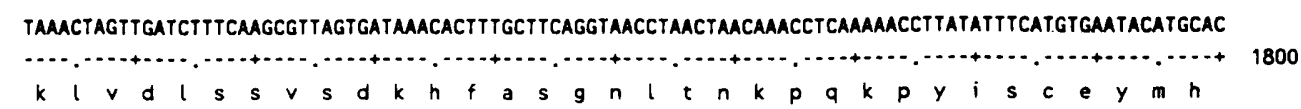

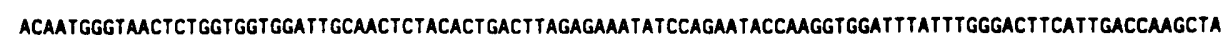

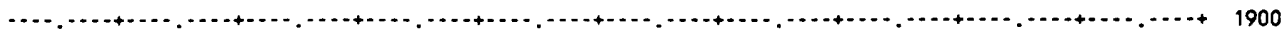
t m g n s g g g l a l y t d l e $k$ y

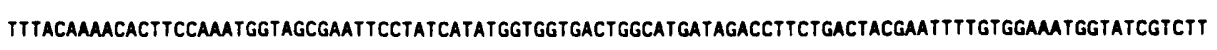

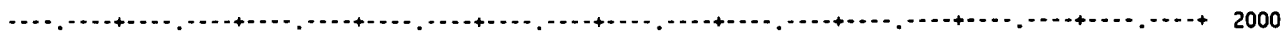

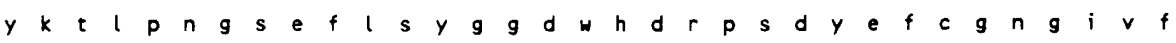
TGCAGATCGTACCCTAACTCCAMAACTTCAAACAGTTAAACATCTTTACTCTAATATTAMGATTGCTGTTGATGAAMATCAGTAACTATCAAGATGAT

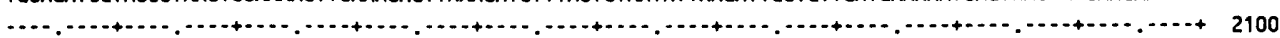

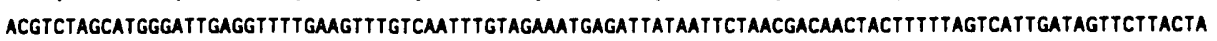

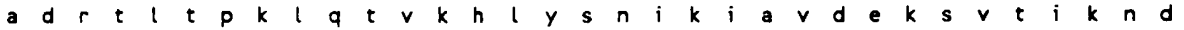

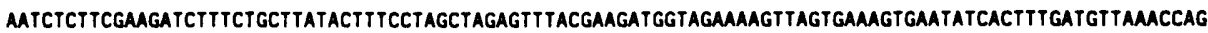

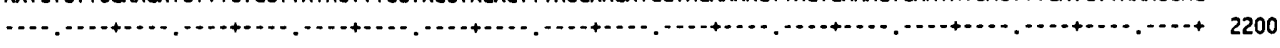
$n l f$ e d l s a y t f l a $r v y$ e d g $r k v s$ e s e y h f d v k p g GCGAAGAGCAACATTCCCAGTTAACTTTGTAGTCGAGGCTTCAAATTCTGAACAAATTTACGAAGTTGCTTGTGTTCTGAGGGAGCAACTGAATGGGC

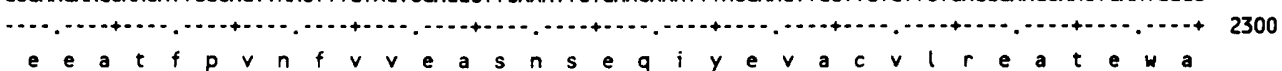

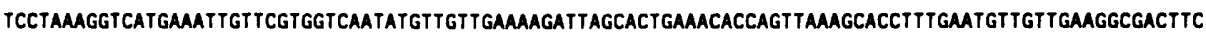

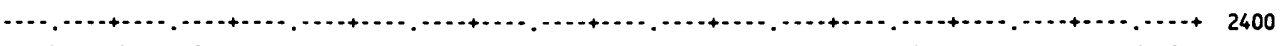

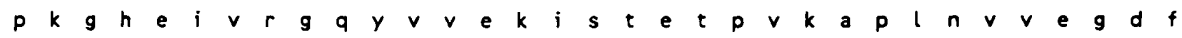

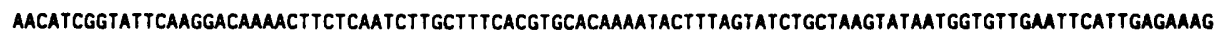

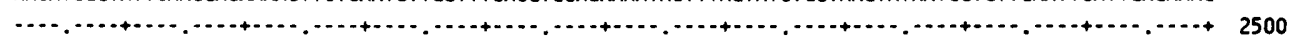

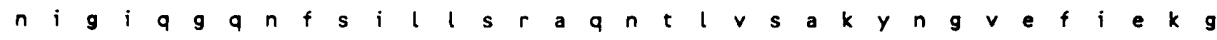

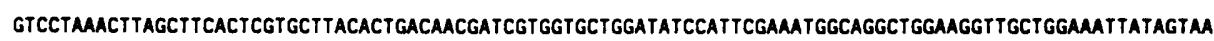

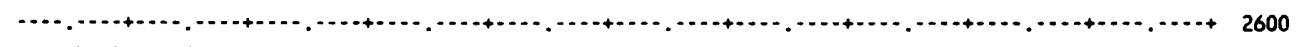

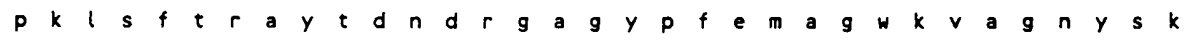

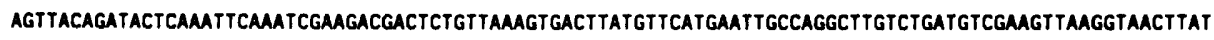

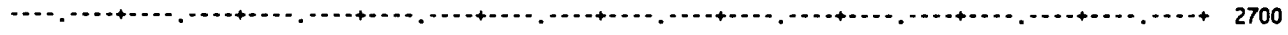

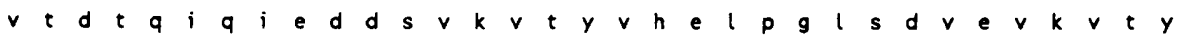

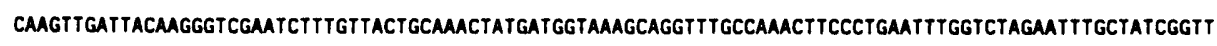

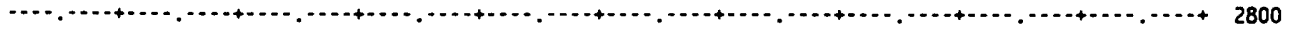
$q \vee d y k g r i f v t a n k d g k a g l p k f p e f g l e f a c i s$

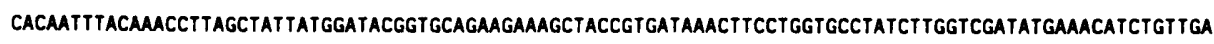

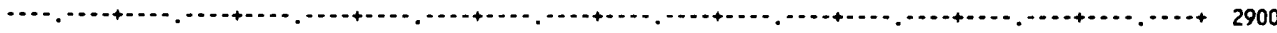

$q f t n l$ s y y g y g a e e s y $r$ d k l p g a y l g r y e t s $v e$

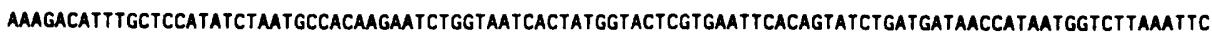

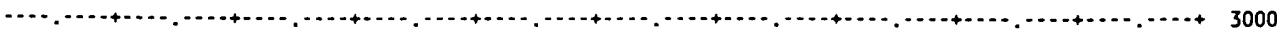

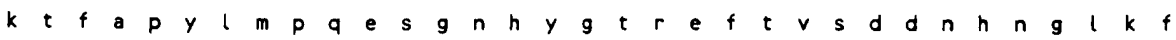
ACCGCACTTAATAAAGCATTCGAATTCAGTGCTTTGCGTAACAGTACTGAACAAATTGAAAATGCTCGTCACCAATATGAGTTGCAAGAATCTGATGCTA

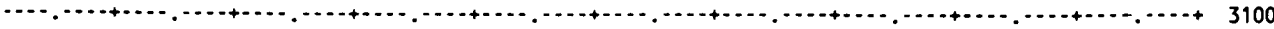

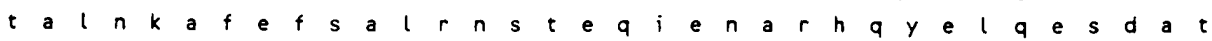

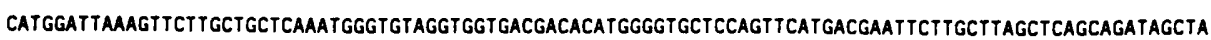

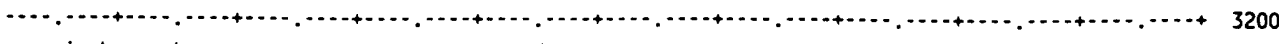

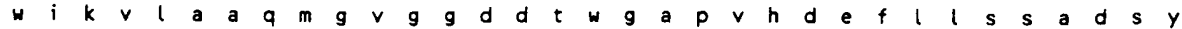

tCAATtAagctTCatgattgaAcCActaAattag -............................... 3234

$q$ l $s$ m $i$ e $p l n$.

Fig. 3. Nucleotide sequence of the $S$. thermophilus lacZ (A054) gene and the deduced amino acid sequence. Putative ribosome-binding sites (RBS), transcription initiation $(-10,-35)$ sites and start sites $(* * *)$ are indicated. 
$63.2 \% \mathrm{~A}-\mathrm{T}$ and $36.8 \% \mathrm{G}-\mathrm{C}$, which corresponds with the approximate values calculated for the thermophilic streptococci (Farrow \& Collins, 1984; Kilpper-Balz et al., 1982). Hydrophobicity analysis of the deduced amino acid sequence showed the Bgal protein to be very hydrophilic, as expected for a cytoplasmic protein (Kyte \& Doolittle, 1982).

DNA sequences obtained both upstream ( $842 \mathrm{bp}$ ) and downstream ( $1528 \mathrm{bp}$ ) from the $l a c Z$ gene from A054 indicate the presence of at least two additional incomplete open reading frames (ORFs), designated ORF280 and ORF231 (A. Mercenier and others, unpublished observations). ORF280, the upstream sequence, is nearly identical to the $3^{\prime}$ region of the DNA sequence of the $S$. thermophilus lactose transport gene (lacS) from the yogurt starter strain A147 (Poolman et al., 1989). Only three bases separate the termination codon of the lacS sequence from the first initiation codon of the $l a c Z$ gene, suggesting that a polycistronic message is produced and that the lactose genes exist as an operon. This was indeed confirmed by Northern analysis (Thomas, 1980; Poolman et al., 1990; P. Slos \& A. Mercenier, unpublished observations). At this time, the function of ORF231 is unknown but, because it lies 835 bp downstream from the lac $Z$ gene, it seems unlikely that ORF231 is related to the lactose operon.

Computer analysis of the region upstream from the first initiation codon (believed to be used in $S$. thermophilus) showed the existence of a consensus ribosome-binding site (RBS; positions 139-145) only 8 bp upstream from the translational start site. However, consensus -35 and -10 regions were only found as far as $80 \mathrm{bp}$ upstream from the putative RBS (see Fig. 3), though this does not exclude the possibility of a functional, secondary internal lac $Z$ promoter in $S$. thermophilus. Relatively large distances between promoter regions and RBSs have been proposed as in the case of the dihydrofolate reductase gene of Lactobacillus casei (Andrews et al., 1985). An inverted repeat of $29 \mathrm{bp}$ was identified at positions 3276-3305, 42 bp downstream from the termination codon (UAG). The hairpin structure that it forms also contains a terminal poly(U) region, suggesting that this structure is a rho-independent terminator.

The cloned fragment carrying the $S$. thermophilus lac $Z$ gene did not contain the $5^{\prime}$ region of the lactose transport gene, and is most probably lacking the authentic lactose promoter on the originally cloned PstI-PstI fragment. However, Bgal expression was observed in strains XL-1 Blue and $\mathrm{JM} 107$ (E. coli $\mathrm{Lac}^{-}$recipients) transformed with $E$. coli or $E$. coli-streptococcal vectors containing the $5.7 \mathrm{~kb}$ PstI-SalI or $3.0 \mathrm{~kb}$ HindIII fragment in either orientation. Because of the high A-T content of $S$. thermophilus DNA, cloned sequences could be fortuitously recognized by $E$. coli as transcriptional starts. Also, it is likely that other in-frame initiation codons (ATG) could be used by $E$. coli. In front of the second (lacZ ATCC 19258) or third (lacZ A054), in-frame ATG, at positions 277-279 (see Fig. 3), a putative RBS at positions 267-273 (TGAGGGG in ATCC 19258, TGAAGGG in A054) was found. This RBS shares strong sequence homology with both the $\operatorname{trp} A$ (GAGGG) and T7 (TGAGGG) RBSs in E. coli (Stormo et al., 1982). In addition, putative -10 and -35 sequences were identified at base positions 241-246 (TATTTT) and 217-222 (GTTGAC in ATCC 19258 and GTTGAT in A054) respectively. The -10 sequence contains the highly conserved and characteristic first, second and last nucleotides required for a Pribnow box, while the putative -35 sequence is homologous with the -35 sequence of the $E$. coli $\operatorname{trp}$ operon (Rosenberg \& Court, 1979). Similar promoter sequences have been isolated from Lactococcus lactis subsp. cremoris chromosomal DNA which have strong sequence homology to both $E$. coli and $B$. subtilis promoters (Van der Vossen et al., 1987). The transcriptional unit from this putative promoter region encodes a protein having a molecular mass of $112195 \mathrm{Da}$. This is similar to the value of $105000 \mathrm{Da}$ determined previously by $E$. coli maxicell analysis (Herman et al., 1987).

Comparison of the DNA sequences of lacZ (ATCC 19258) and lacZ (A054) showed 21 base differences within the structural gene (Table 2). Of these, only nine resulted in amino acid residue differences between the $\mathrm{LacZ}$ proteins, and of these nine, four were conservative. The remaining 12 base differences were in wobble positions having no effect on the protein sequence. Base 270 , which is a guanine in lacZ (ATCC 19258) and an adenine in lac $Z$ (A054), lies within or near the secondary RBS and might alter the translation efficiency of the putative secondary transcriptional unit.

\section{Analysis of the LacZ protein sequence}

When the predicted amino acid sequences were compared, the Bgals from L. bulgaricus, E. coli and Klebsiella pneumoniae exhibited 48,35 and $32.5 \%$ identity respectively with the $S$. thermophilus protein (Schmidt $e t$ al., 1989; Kalnins et al., 1983; Buvinger \& Riley, 1985). The amino acid sequences from $S$. thermophilus, L. bulgaricus and E. coli were aligned (Fig. 4), and distinct regions of strong conservation were identified. Predictions of secondary structures with the algorithm of Chou \& Fasman (1974) showed that most of these regions were contained either within beta sheets or at the ends of beta sheets at alpha turns in the protein structure. From this information, it can be hypothesized that domains having catalytic functions or providing structural integrity were 
Table 2. Base and amino acid differences between lac $Z$ (A054) and lacZ (ATCC 19258)

\begin{tabular}{ccccc}
\hline $\begin{array}{c}\text { Base } \\
\text { position* }\end{array}$ & $\begin{array}{c}\text { Base change } \\
\text { (A054 to 19258) }\end{array}$ & $\begin{array}{c}\text { Codon } \\
\text { position }\end{array}$ & $\begin{array}{c}\text { Amino acid } \\
\text { change }\end{array}$ & $\begin{array}{c}\text { Conservative } \\
\text { change }\end{array}$ \\
\hline 161 & $\mathrm{~T} \rightarrow \mathrm{C}$ & 2 & Met $\rightarrow \mathrm{Thr}$ & No \\
183 & $\mathrm{~T} \rightarrow \mathrm{C}$ & 3 & None & - \\
222 & $\mathrm{~T} \rightarrow \mathrm{C}$ & 3 & None & - \\
257 & $\mathrm{~A} \rightarrow \mathrm{C}$ & 2 & Glu $\rightarrow$ Ala & No \\
270 & $\mathrm{~A} \rightarrow \mathrm{G}$ & 3 & None & - \\
453 & $\mathrm{~A} \rightarrow \mathrm{G}$ & 3 & None & - \\
1051 & $\mathrm{G} \rightarrow \mathrm{A}$ & 1 & Asp $\rightarrow$ Asn & No \\
1200 & $\mathrm{C} \rightarrow \mathrm{T}$ & 3 & None & - \\
1566 & $\mathrm{C} \rightarrow \mathrm{T}$ & 3 & None & - \\
1722 & $\mathrm{C} \rightarrow \mathrm{A}$ & 3 & Ser $\rightarrow$ Arg & No \\
1828 & $\mathrm{C} \rightarrow \mathrm{G}$ & 1 & Gln $\rightarrow$ Glu & No \\
1995 & $\mathrm{C} \rightarrow \mathrm{T}$ & 3 & None & - \\
2104 & $\mathrm{C} \rightarrow \mathrm{G}$ & 1 & Leu $\rightarrow$ Val & Yes \\
2152 & $\mathrm{G} \rightarrow \mathrm{A}$ & 2 & Ser $\rightarrow$ Glu & Yes \\
2367 & $\mathrm{~T} \rightarrow \mathrm{C}$ & 3 & None & - \\
2394 & $\mathrm{C} \rightarrow \mathrm{T}$ & 3 & None & - \\
2513 & $\mathrm{G} \rightarrow \mathrm{A}$ & 2 & Ser $\rightarrow$ Asn & Yes \\
2574 & $\mathrm{C} \rightarrow \mathrm{A}$ & 3 & None & - \\
2592 & $\mathrm{~T} \rightarrow \mathrm{C}$ & 3 & None & - \\
2709 & $\mathrm{~T} \rightarrow \mathrm{C}$ & 3 & None & - \\
3148 & $\mathrm{~A} \rightarrow \mathrm{T}$ & 1 & Thr $\rightarrow$ Ser & Yes \\
\hline \hline
\end{tabular}

* Base position relative to Fig. 3 .

$\dagger$ Position in the 3-base codon where position 3 is the wobble position.

maintained. Two examples are very apparent. The region containing the putative active-site residues for Bgal, determined in the $E$. coli protein to be at amino acid positions Glu-461 (Herrchen \& Legler, 1984) and Tyr503 (Naider et al., 1972; Fowler et al., 1978), and the region involved in the formation of the tetrameric structure of Bgal at the carboxyterminal region of the protein (Mandecki et al., 1981), are all highly conserved and are included within three of the conserved regions in Fig. 4. This suggests that all four Bgals may have evolved from a common ancestral gene.

\section{Discussion}

In this study, the lac $Z$ gene from $S$. thermophilus strain A054, a yogurt starter strain, was cloned and compared by DNA sequence analysis to the homologous gene from the type strain $S$. thermophilus ATCC 19258. A054 and ATCC 19258 differed markedly in their abilities to coagulate milk ( $4-5 \mathrm{~h}$ at $44^{\circ} \mathrm{C}$ for A054 versus more than $10 \mathrm{~h}$ for ATCC 19258; A. Mercenier and others, unpublished observations). At the DNA level, however only 21 base differences were identified between the lac $Z$ genes from strains A054 and ATCC 19258, of which only nine resulted in amino acid changes (five non-conservative and four conservative) in the protein sequence
(Table 2). The few DNA base changes observed and the subsequent amino acid substitutions in the protein demonstrate that there is little difference between these genes (less than $1 \%$ ). The differences in milk clotting rates could be due to a number of reasons, including differences in the efficiency of lactose uptake or proteolytic capacity.

In comparing the DNA sequences of the lac $Z$ genes from $E$. coli and two lactic acid bacteria, $S$. thermophilus and $L$. bulgaricus, little or no sequence identity was apparent. When the deduced protein sequences were aligned, however, several observations were made. The sequences of the $S$. thermophilus and $L$. bulgaricus proteins showed $48 \%$ similarity. When all three protein sequences were aligned, regions of conserved protein sequence were apparent that most likely represent domains for secondary structure maintenance and enzymatic function. It is interesting to note that no protein similarity could be detected between the Bgals and the Pbgs of other dairy starters.

So far, the molecular organization of the lactose utilization genes appears to be very similar in $S$. thermophilus and $L$. bulgaricus, the two symbiotic organisms used in making yogurt. Lactose is transported into both organisms by a hybrid protein which, in part, resembles certain PEP-PTS components (Poolman et al., 1989). The genes that encode these protonmotive-force- 


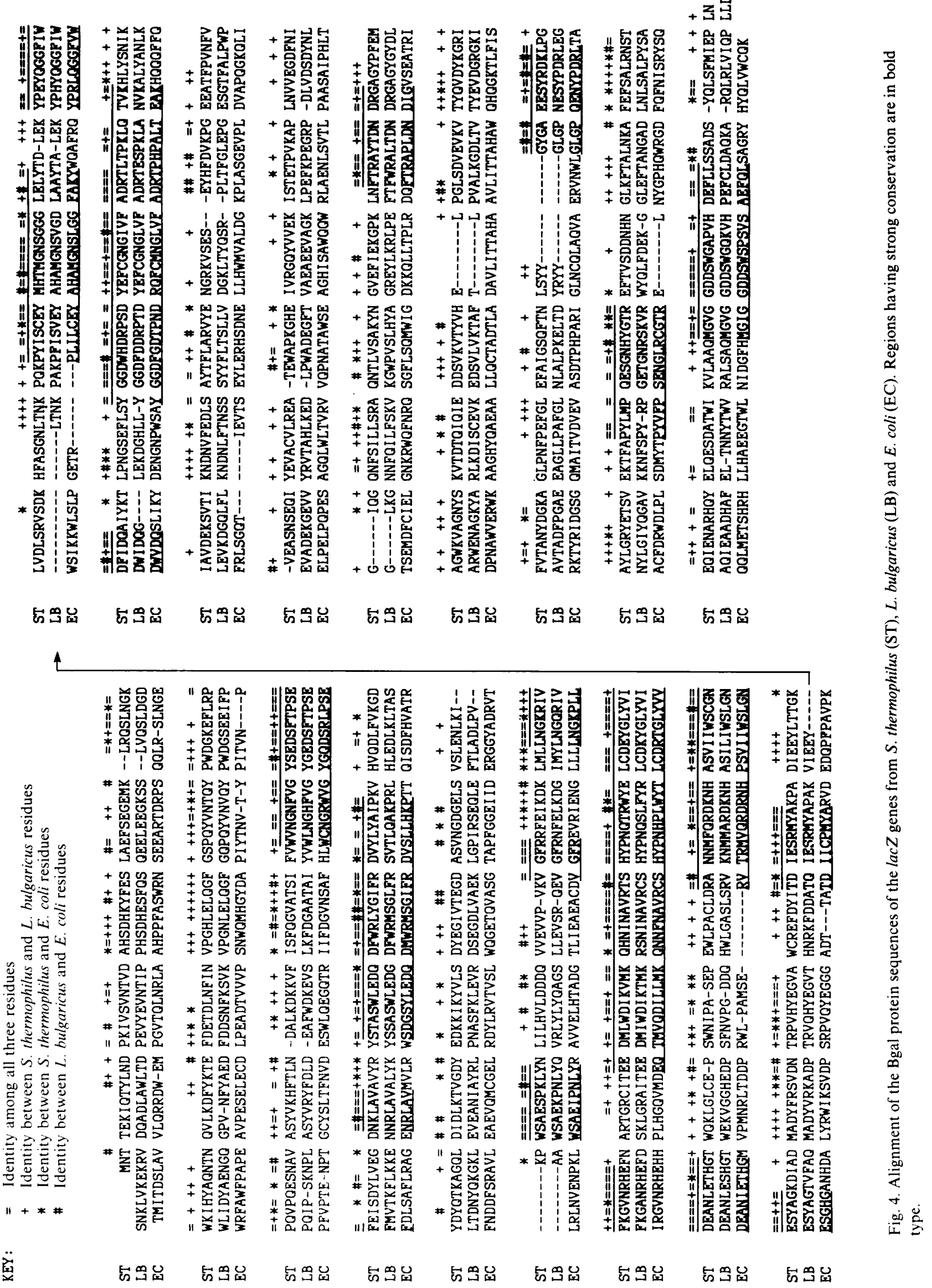


linked lactose transport systems demonstrate $60 \%$ similarity in S. thermophilus and L. bulgaricus (lacS and lacL, respectively; Poolman et al., 1989). In both species, they are separated from the respective structural gene of the lactose-hydrolysing enzyme by only three bases. In the case of $L$. bulgaricus, it has been shown by sequencing of the amino-terminal end of the purified Bgal that the first ATG in frame (located 3 bp downstream from lacL) was indeed the translational start (Schmidt et al., 1989). By analogy, and as supported by Northern analysis, this is probably the case for $S$. thermophilus as well. We believe that in both species the lactose genes are organized, at least in part, as an operon. However, in the case of $S$. thermophilus, a second initiation codon, preceded by a putative RBS and promoter sequence, could be identified 112 bp downstream from the first ATG start site. All constructions carrying the minimal lac $Z$ insert complemented the $\mathrm{Lac}^{-}$defect in $E$. coli lac $Z$ mutant strains (leading to blue colonies on X-Gal plates). This suggests that the putative internal promoter, carried on the $3 \mathrm{~kb}$ HindIII fragment, could be recognized at least in E. coli. Whether these sequences are utilized by $S$. thermophilus as a minor re-initiation site is not known. Secondary transcription and translation may be a fortuitous consequence in $E$. coli due to the A-T richness of the $S$. thermophilus DNA. This hypothesis is also supported by the slightly reduced size of the cloned Bgal from S. thermophilus ATCC 19258 observed in transformed E. coli maxicells (Herman et al., 1987). It is notable that, while there is a definite similarity between the Bgals of E. coli and $S$. thermophilus, these two species differ completely in their respective lactose transport systems. No similarity could be detected between the lac $S$ protein of $S$. thermophilus and the lactose permease (lacY) from E. coli.

In general, the codon usage deduced from the $l a c Z$ nucleotide sequence fits well with that reported from the lacS gene of $S$. thermophilus (Poolman et al., 1989). For example, the codons CCC (proline), CCG (proline) and CGG (arginine) were not found in either gene. Other rare codons in one gene, for example ACG (threonine) in $l a c S$ and CUG (leucine) in lacZ, were absent in the other gene. As expected from the DNA base composition of $S$. thermophilus $(63 \% \mathrm{~A}-\mathrm{T})$, there is a strong propensity, as determined from the existing sequences, for A-T richness.

Further work that may be of interest with the lac $Z$ gene might include a more detailed study of the secondary $l a c Z$ promoter. This aspect has potential in the development of new $E$. coli-streptococcal-lactococcal shuttle vectors. Considering that the lac $Z$ gene lacks its own promoter, it would make an ideal marker for a promoter probe vector, whereby promoter sequences from different lactic acid bacteria could be selected.
We would like to thank J. P. Lecocq for his interest in this project and $\mathrm{Y}$. Lemoine for stimulating discussions. We acknowledge $\mathrm{D}$. Villeval for preliminary sequence data on lac Z (A054). We appreciated the critical manuscript corrections of T. Achstetter, J. Jacobson, J. Singer, K. Polzen, K. Baldwin and S. Harlander.

This research was supported in part by the National Dairy Promotion and Research Board, Logan, UT, by General Mills Inc., Minneapolis, MN, and by Hatch and General Agricultural Research Funds (project 18-62).

This is paper no. 17812 of the contribution series of the Minnesota Agricultural Experiment Station.

\section{References}

Alpert, C. A. \& Chassy, B. M. (1988). Molecular cloning and nucleotide sequence of the factor III lac gene of Lactobacillus casei. Gene 62, 277-288.

Andrews, J., Clore, G. M., Davies, R. W., Gronenborn, A. M., Gronenborn, B., Kalderon, D., Papadopoulos, P. C., Schafer, S., Sims, P. F. C. \& Stancombe, R. (1985). Nucleotide sequence of the dihydrofolate reductase gene of methotrexate-resistant Lactobacillus casei. Gene 35, 217-222.

APPLEYARD, R. K. (1954). Segregation of new lysogenic types during growth of a doubly lysogenic strain derived from Escherichia coli K12. Genetics 39, 440-452.

Bankier, A. T. \& Barrell, B. G. (1983). Techniques in the life sciences, B5. In Nucleic Acids Biochemistry, B508, pp. 1-34. Shannon, Ireland: Elsevier Scientific Publishers.

Boizet, B., Villeval, D., Slos, P., Novel, M. \& Mercenier, A. (1988). Isolation and structural analysis of the phospho- $\beta$ galactosidase gene from Streptococcus lactis Z268. Gene 62, 249-261.

Bolivar, F., Rodriguez, R. L., Greene, P. J., Betlach, M. C., HeYNECKER, H. L. \& BOYER, H. W. (1977). Construction and characterization of new cloning vehicles. II. A multi-purpose cloning system. Gene 2, 95-113.

Bullock, W. O., Fernandez, J. M. \& Short, J. M. (1987). XL-1 Blue: a high efficiency plasmid transforming recA Escherichia coli strain with beta-galactosidase selection. BioTechniques 5, 376-378.

Buvinger, W. E. \& RiLEY, M. (1985). Nucleotide sequence of Klebsiella pneumoniae genes. Journal of Bacteriology 163, 850-857.

Chou, P. Y. \& Fasman, G. D. (1974). Prediction of protein conformation. Biochemistry 13, 222-245.

Crow, V. L. \& Thomas, T. D. (1984). Properties of a Streptococcus lactis strain that ferments lactose slowly. Journal of Bacteriology 157 , 28-34.

DAO, M. L. \& FerRetTI, J. J. (1985). Streptococcus-Escherichia coli shuttle vector pSA3 and its use in the cloning of streptococcal genes. Applied and Environmental Microbiology 49, 115-119.

Demerec, M., Adelberg, E. A., Clark, A. J. \& Hartman , P. E. (1966). A proposal for a uniform nomenclature in bacterial genetics. Genetics 54, 61-76.

DeVos, W. M. \& Simons, G. (1988). Molecular cloning of lactose genes in dairy lactic streptococci: the phospho- $\beta$-galactosidase and $\beta$ galactosidase genes and their expression products. Biochimie $\mathbf{7 0}, 461-$ 473.

DeVos, W. M., Vos, P., Simons, G. \& David, S. (1989). Gene organization and expression in mesophilic lactic acid bacteria. Journal of Dairy Science 72, 3398-3405.

Elliker, P. R., Anderson, A. W. \& Hannesson, G. (1956). An agar culture medium for lactic acid streptococci and lactobacilli. Journal of Dairy Science 89, 1611-1612.

FarRow, J. A. E. \& Collins, M. D. (1984). DNA base composition, DNA-DNA homology and long chain fatty acid studies on Streptococcus thermophilus and Streptococcus salivarius. Journal of General Microbiology 130, 357-362.

Fowler, A. V., Zabin, I., Sinnett, M. L. \& Smith, P. J. (1978). Methionine 500 , the site of covalent attachment of an active sitedirected reagent of $\beta$-galactosidase. Journal of Biological Chemistry 253, 5283-5285. 
Gasson, M. (1987). Streptococcal cloning vectors (Appendix A). In Streptococcal Genetics, p. 273. Edited by J. J. Ferretti \& R. Curtiss, III. Washington, DC: American Society for Microbiology.

HANAHAN, D. (1983). Studies on transformation of Escherichia coli with plasmids. Journal of Molecular Biology 166, 557-580.

HENIKOFF, S. (1984). Unidirectional digestion with exonuclease III creates targeted breakpoints for DNA sequencing. Gene 28, 351-359.

Herman, R. E. \& McKaY, L. L. (1986). Cloning and expression of the $\beta$-D-galactosidase gene from Streptococcus thermophilus in Escherichio coli. Applied and Environmental Microbiology 52, 45-50.

Herman, R. E., Schroeder, C. J. \& MCKay, L. L. (1987). Characterization of plasmids and cloning of the $\beta$-galactosidase gene from Streptococcus thermophilus. In Streptococcal Genetics, pp. 225 228. Edited by J. J. Ferretti \& R. Curtiss, III. Washington DC: American Society for Microbiology.

HERRCHEN, M. \& LEGLER, G. (1984). Identification of an essential carboxylate group at the active site of the lac $Z \beta$-galactosidase from Escherichia coli. European Journal of Biochemistry 138, 527-531.

Holmes, D. S. \& QuigleY, M. (1981). A rapid boiling method for the preparation of bacterial plasmids. Analytical Biochemistry 114, 193197.

Kalnins, A., Otto, K., Ruther, U. \& Muller-Hill, B. (1983). Sequence of the lacZ gene of Escherichia coli. EMBO Journal 2, 593597.

KiENY, M. P., LATHE, R. \& LeCOCQ, J. P. (1983). New versatile cloning and sequence vectors based on bacteriophage M13. Gene 26, 91-99.

Kilpper-Balz, R., Fischer, G. \& SChleifer, K. H. (1982). Nucleic acid hybridization of group N and group D streptococci. Current Microbiology 7, 245-250.

KonDo, J. K. \& MCKAY, L. L. (1982). Transformation of Streptococcus lactis protoplasts by plasmid deoxyribonucleic acid. Applied and Environmental Microbiology 43, 1213-1215.

KYTE, J. \& DoolitTle, R. F. (1982). A method for displaying the hydropathic character of a protein. Journal of Molecular Biology 157, $105-132$

LARSON, R. \& MESSING, J. (1982). Apple II software for M13 shotgun DNA sequencing. Nucleic Acids Research 10, 39-49.

Macrina, F. L., Evans, R. P., Tobian, J. A., Hartley, D. L. Clewell, D. B. \& Jones, K. R. (1983). Novel shuttle plasmid vehicles for Escherichia-Streptococcus transgenic cloning. Gene 25, $145-150$

MANDECKI, W., Fowler, A. V. \& ZABIN, I. (1981). Position of the lacZ $x 90$ mutation and hybridization between complete and incomplete $\beta$-galactosidase. Journal of Bacteriology 147, 694-697.

Maniatis, T., Fritsch, E. F. \& SambrooK, J. (1982). Molecular Cloning: a Laboratory Manual. Cold Spring Harbor, NY: Cold Spring Harbor Laboratory.

McKay, L. L., Baldwin, K. A. \& Walsh, P. M. (1980). Conjugal transfer of genetic information in group $\mathrm{N}$ streptococci. Applied and Environmental Microbiology 40, 84-91.

Mercenier, A. \& Lemoine, Y. (1989). Genetics of Streptococcus thermophilus: a review. Journal of Dairy Science 72, 3444-3454.

Mercenier, A., Robert, C., Romero, D. A., Castellino, I., Silos, P. \& LEMOINE, Y. (1988). Development of an efficient spheroplast transformation procedure for Streptococcus thermophilus: the use of transfection to define a regeneration medium. Biochimie 70, 567-577.

Miller, J. H. (1972). Experiments in Molecular Genetics. Cold Spring Harbor, NY: Cold Spring Harbor Laboratory.
NAIDER, F., BOHAK, Z. \& YARIV, J. (1972). Reversible alkylation of a methionyl residue near the active site of $\beta$-galactosidase. Biochemistry 11, 3202-3207.

Poolman, B., Royer, T. J., Mainzer, S. E. \& Schmidt, B. F. (1989). Lactose transport system of Streptococcus thermophilus: a hybrid protein with homology to the melibiose carrier and enzyme III of phosphoenolpyruvate-dependent phosphotransferase systems. Journal of Bacteriology 171, 244-253.

Poolman, B., Royer, T. J., Mainzer, S. E. \& Schmidt, B. F. (1990). Carbohydrate utilization in Streptococcus thermophilus: characterization of the genes for aldolase 1-epimerase (mutarotase) and UDPglucose 4-epimerase. Journal of Bacteriology 172, 4037-4047.

PorTer, E. V. \& Chassy, B. M. (1988). Nucleotide sequence of the $\beta$-Dphosphogalactoside galactohydrolase gene of Lactobacillus casei: comparison to analogous pbg genes of other Gram-positive organisms. Gene 62, 263-276.

ROSENBERG, M. \& COURT, D. (1979). Regulatory sequences involved in the promotion and termination of RNA transcription. Annual Review of Genetics 13, 319-353.

SANGer, F., Nicklen, S. \& Coulson, A. R. (1977). DNA sequencing with chain-terminating inhibitors. Proceedings of the National Academy of Sciences of the United States of America 74, 5463-5467.

Schmidt, B. F., Adams, R. M., ReQuadt, C., Power, S. \& Mainzer, S. E. (1989). Expression and nucleotide sequence of the Lactobacillus bulgaricus $\beta$-galactosidase gene cloned in Escherichia coli. Journal of Bacteriology 171, 625-635.

Somkuti, G. A. \& Steinberg, D. M. (1979). $\beta$-D-Galactoside galactohydrolase of Streptococcus thermophilus: induction, purification and properties. Journal of Applied Biochemistry 1, 357-368.

SOUTHERN, E. (1975). Detection of specific sequences among DNA fragments separated by gel electrophoresis. Journal of Molecular Biology 98, 503-517.

Stormo, G. D., Schneider, T. D. \& Gold, L. M. (1982). Characterization of translational initiation sites in E. coli. Nucleic Acids Research 10, 2971-2995.

TABOR, S. \& RICHARDSON, C. C. (1987). DNA sequence analysis with a modified bacteriophage T7 DNA polymerase. Proceedings of the National Academy of Sciences of the United States of America 84, 4767-4771.

TERZAGHI, B. K. \& SANDINE, N. R. (1975). Improved medium for lactic streptococci and their bacteriophages. Applied and Environmental Microbiology 29, 807-813.

ThомAs, P. S. (1980). Hybridization of denatured RNA and small DNA fragments transferred to nitrocellulose. Proceedings of the National Academy of Sciences of the United States of America 77, 5201-5205.

VAN der Vossen, J. M. B. M., Van der Lelie, D. \& Venema, G (1987). Isolation and characterization of Streptococcus cremoris Wg2specific promoters. Applied and Environmental Microbiology 53, 2452-2457.

WinBerG, G. \& HAMmERSKJolA, M. L. (1980). Isolation of DNA from agarose gels using DEAE-paper. Applications to restriction site mapping of adenovirus type 16 DNA. Nucleic Acids Research 8, 253264.

Yanisch-Perron, C., Vieira, J. \& Messing, J. (1985). Improved M13 phage cloning vectors and host strains: nucleotide sequences of the M13mp18 and pUC19 vectors. Gene 33, 103-119. 